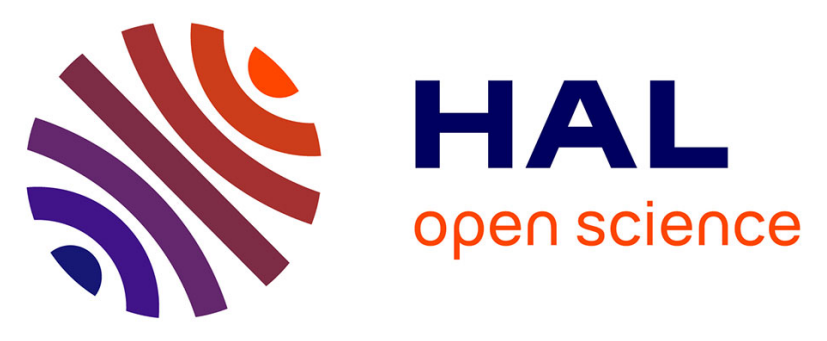

\title{
Kinetic modeling using temperature as an on-line measurement: Application to the hydrolysis of acetic anhydride, a revisited kinetic model
}

Elizabeth Antonia Garcia-Hernandez, Camilla Ribeiro Souza, Lamiae

Vernières-Hassimi, Sébastien Leveneur

\section{To cite this version:}

Elizabeth Antonia Garcia-Hernandez, Camilla Ribeiro Souza, Lamiae Vernières-Hassimi, Sébastien Leveneur. Kinetic modeling using temperature as an on-line measurement: Application to the hydrolysis of acetic anhydride, a revisited kinetic model. Thermochimica Acta, 2019, 682, pp.178409. 10.1016/j.tca.2019.178409 . hal-02435541

\section{HAL Id: hal-02435541}

https://hal-normandie-univ.archives-ouvertes.fr/hal-02435541

Submitted on 21 Dec 2021

HAL is a multi-disciplinary open access archive for the deposit and dissemination of scientific research documents, whether they are published or not. The documents may come from teaching and research institutions in France or abroad, or from public or private research centers.
L'archive ouverte pluridisciplinaire HAL, est destinée au dépôt et à la diffusion de documents scientifiques de niveau recherche, publiés ou non, émanant des établissements d'enseignement et de recherche français ou étrangers, des laboratoires publics ou privés.

\section{(ㄷ)(1) $\$$}

Distributed under a Creative Commons Attribution - NonCommerciall 4.0 International 


\section{Kinetic modeling using temperature as an on-line measurement:}

Elizabeth Antonia Garcia-Hernandez ${ }^{1}$, Camilla Ribeiro Souza ${ }^{l}$, Lamiae Vernières-Hassimi ${ }^{l}$,

4 Sébastien Leveneur ${ }^{* 1,2}$

${ }^{1}$ Normandie Univ, INSA Rouen, UNIROUEN, LSPC, EA4704, 76000 Rouen, France, E-mail: sebastien.leveneur@insa-rouen.fr

Abstract. The use of calorimeter in chemical reaction engineering is a powerful tool to estimate kinetic constants. Indeed, reaction temperature is used as an online analytical signal.

11 Nevertheless, the thermal characterization of the calorimeter must be done to avoid wrong estimation. The hydrolysis of acetic anhydride was used as a reaction model in a handmade calorimeter, because it is a fast and exothermic reaction. Several research groups have studied this reaction without taking into account the autocatalytic effect due to the production of acetic acid. To fill this gap, a kinetic model was developed by taking this phenomenon and in a thermally characterized handmade calorimeter. The estimated kinetic constants in the handmade calorimeter were found to be similar than in the established calorimeter Mettler Toledo RC1. 


\section{HIGHLIGHTS}

22 Thermal characterization of a calorimeter

23 Kinetic model using reaction temperature as online observable

24 Kinetic model for acetic anhydride hydrolysis taking into account autocatalytic effect

25

26 
Calorimetry is a science that finds its roots with the works of Joseph Black, Antoine Lavoisier and Pierre-Simon Laplace. It is an important thermal analytical tool in different fields such as material science, polymer, chemistry or chemical engineering. One can get fundamental thermal and thermodynamic data of different compounds by using different thermal modes.

In chemical engineering, calorimetry allows to measure/estimate specific heat capacities of chemicals [1-4] and reaction enthalpies [5-7] . It is also the appropriate tool in process safety and more particularly in thermal risk assessment to determine risk parameters such as time-tomaximum-rate under adiabatic conditions $\mathrm{TMR}_{\mathrm{ad}}$ or adiabatic temperature rise $\Delta \mathrm{T}_{\mathrm{ad}}$. The knowledge of these safety parameters allow to evaluate the thermal risk of a chemical process [7-12] .

Another benefit of calorimeter is in chemical reaction engineering, where reaction temperature is used as an online measurement signal. The use of calorimeter to estimate rate constants has significantly increased these last years, essentially for fast and exothermic reactions.

The use of reaction temperature or heat-flow rate released as online signals to evaluate the kinetics of a reaction was used by several research groups [13-19] . The development of calorimeters has participated to the development of this approach. Nevertheless, one should also take into account different thermal phenomena such as specific heat capacity of the inserts or heat loss [16] .

Hydrolysis of acetic anhydride is frequently used as a calibration reaction for calorimeters $[13,20]$. This reaction was studied by several research groups: 
-Wiseman [21] used $\mathrm{pH}$ as an online analytical method but he did not include the energy balance,

-Susanne et al. [22] used NMR as an online method but they did not include energy balance,

-Hirota et al.[23] have used the temperature to make the kinetic estimation without taking into account the autocatalytic effect of the reaction,

-Zogg et al. [24,25] studied this reaction by combining calorimetric and IR techniques, but they assumed a first order reaction,

-Gomez Garcia et al. [26] used this reaction as an example for thermal stability,

-Asiedu et al. [27] studied this reaction under adiabatic mode but with a first order approach.

This reaction is known to be autocatalytic due to the dissociation of the product acetic acid. Nevertheless, none of these research groups have developed a kinetic model taking into account this phenomenon for this reaction.

The objective of this article is to develop a kinetic model including the autocatalytic effect and the different thermal phenomena. To estimate the kinetic constants, experiments under isoperibolic mode was performed in a hand-made calorimeter. The thermal properties of this calorimeter were investigated. To validate the developed kinetic model in the hand-made calorimeter, a comparison with the RC1 Mettler-Toledo calorimeter was done. 


\subsection{Materials}

69 The following chemicals were used: ACS reagent acetic anhydride (purity $\geqslant 99 \%$ ) and

70 distilled water.

\section{2.2. Experimental Setup}

72 Kinetic experiments for the hydrolysis of acetic anhydride were carried out in the hand-made

73 calorimeter composed of a $300 \mathrm{~mL}$ jacketed glass reactor equipped with accurate temperature

74 probes, a calibration probe to measure the global heat transfer coefficient, a mechanical stirrer 75 and reflux condenser. The internal diameter of the jacketed reactor was $10 \mathrm{~cm}$, and the 76 mechanical stirrer was a pitched blade turbine impeller (diameter $3.8 \mathrm{~cm}$ and 4 blades). The 77 inlet temperature of condenser was fixed at $10^{\circ} \mathrm{C}$ to avoid the loss of liquid phase compounds. 78 Experiments were performed under isoperibolic and semi-batch mode. Fig. 1 shows a 79 simplified scheme of the reactor setup. 


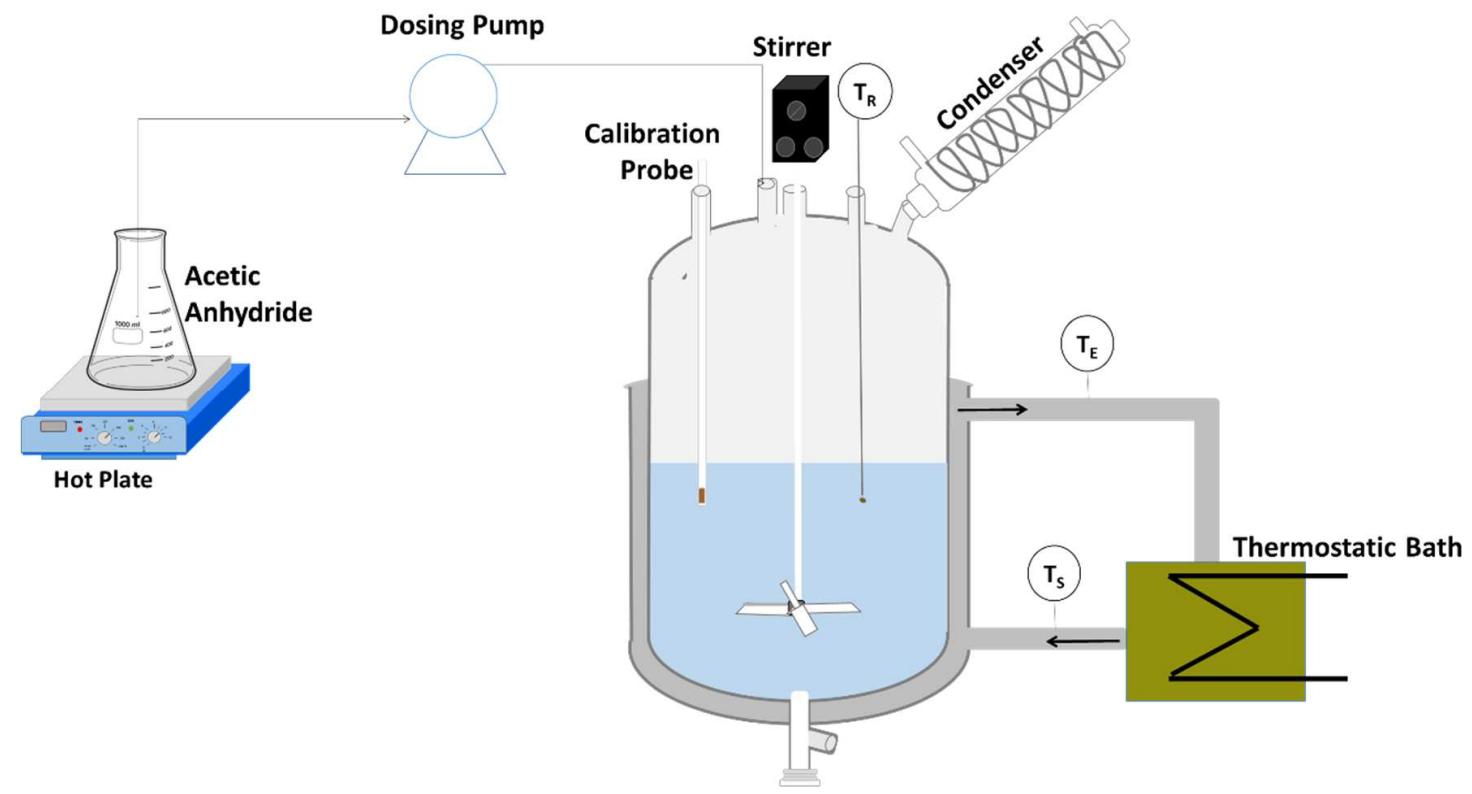

Fig. 1. Schematic representation of the experimental setup.

2.3 Thermal characterization of the calorimeter

The goals of these experiments are to measure the heat transfer coefficient between the reaction mixture and heat carrier, evaluate the heat loss and measure the specific heat capacities of the inserts.

\section{- Measurement of heat transfer coefficient}

To determine the heat transfer coefficient, an electrical calibration was used. For that, the reactor was filled with a solution and heated to the desired temperature in the absence of reaction and under isoperibolic conditions. When the solution temperature was stable, a known electrical power (Joule heating) was provided for around 10 minutes and then switched off. The evolution of the solution temperature was recorded. One can find a detailed description of this method in previous article of our group [28,29]. 
96 The procedure described in reference [30] was used. The thermostatic bath was set to a 97 temperature but the heat carrier did not circulate in the reactor jacket. At the same time the 98 reactor was filled with water at room temperature. When the thermostatic bath reached the

99 desired temperature, the pump system was switched on to allow the circulation of the heat 100 carrier in the jacket. Both temperature, jacket and water temperature were recorded. These 101 measurements were carrying out at three different temperatures $\left(40,60\right.$ and $\left.80{ }^{\circ} \mathrm{C}\right)$. - Evaluation of heat loss

103 The thermostatic bath was set at a temperature and the circulation of the heat carrier was 104 switched on. The reactor was filled with water and heated to the desired temperature. When the 105 water temperature was at the same temperature as the jacket one, the circulation of the heat 106 carrier stopped (defined as time zero) and removed from the jacket. The water temperature was 107 recorded. The experiments were carrying out at three different temperatures $\left(40,60\right.$ and $\left.80{ }^{\circ} \mathrm{C}\right)$.

$108 \quad 2.4$ Kinetic experiments in calorimeter

109 Kinetic experiments were performed in semi-batch mode where acetic anhydride was added 110 into the reactor. Table 1 shows the experimental matrix. 
114 Table 1

115 Experimental matrix in handmade calorimeter with an agitation speed of $400 \mathrm{rpm}$.

\begin{tabular}{|c|c|c|c|c|c|c|}
\hline RUN & $\begin{array}{c}\text { Added } \\
\text { volume of } \\
\text { acetic } \\
\text { anhydride } \\
\text { (L) }\end{array}$ & $\begin{array}{c}\text { Time of } \\
\text { addition (s) }\end{array}$ & $\begin{array}{c}\text { Acetic } \\
\text { anhydride } \\
\text { volumetric flow } \\
\text { rate }\left(\mathrm{L} \mathrm{s}^{-1}\right)\end{array}$ & $\begin{array}{c}\text { Initial } \\
\text { volume of } \\
\text { water }(\mathrm{L})\end{array}$ & $\begin{array}{c}\text { Initial } \\
\text { jacket and } \\
\text { reaction } \\
\text { temperature } \\
\left({ }^{\circ} \mathrm{C}\right)\end{array}$ & $\begin{array}{c}\text { Feed } \\
\text { temperature } \\
\left({ }^{\circ} \mathbf{C}\right)\end{array}$ \\
\hline 1 & 0.09 & 7.00 & 0.0128 & 0.19 & 30.07 & 27.00 \\
\hline 2 & 0.09 & 7.00 & 0.0128 & 0.19 & 39.73 & 28.00 \\
\hline 3 & 0.09 & 7.00 & 0.0128 & 0.19 & 49.34 & 48.00 \\
\hline 4 & 0.09 & 7.00 & 0.0128 & 0.19 & 59.17 & 58.00 \\
\hline 5 & 0.13 & 600.00 & 0.0002 & 0.14 & 49.58 & 23.00 \\
\hline
\end{tabular}

116

1172.5 Kinetic experiment in Mettler Toledo calorimeter RC1

118 The Mettler ${ }^{\mathrm{TM}} \mathrm{RC} 1$ is a jacketed-glass reactor calorimeter of $2 \mathrm{~L}$ presented in Fig. 2. It is

119 equipped with a Pt100 temperature probe, an electrical calibration heating and a feed system (a

120 dosing pump and a balance, with measurement of the feed temperature). The heating-cooling

121 system works within a temperature range of -15 to $+200^{\circ} \mathrm{C}$. WinRCNT software solves the

122 energetic balance on the reaction mass. 


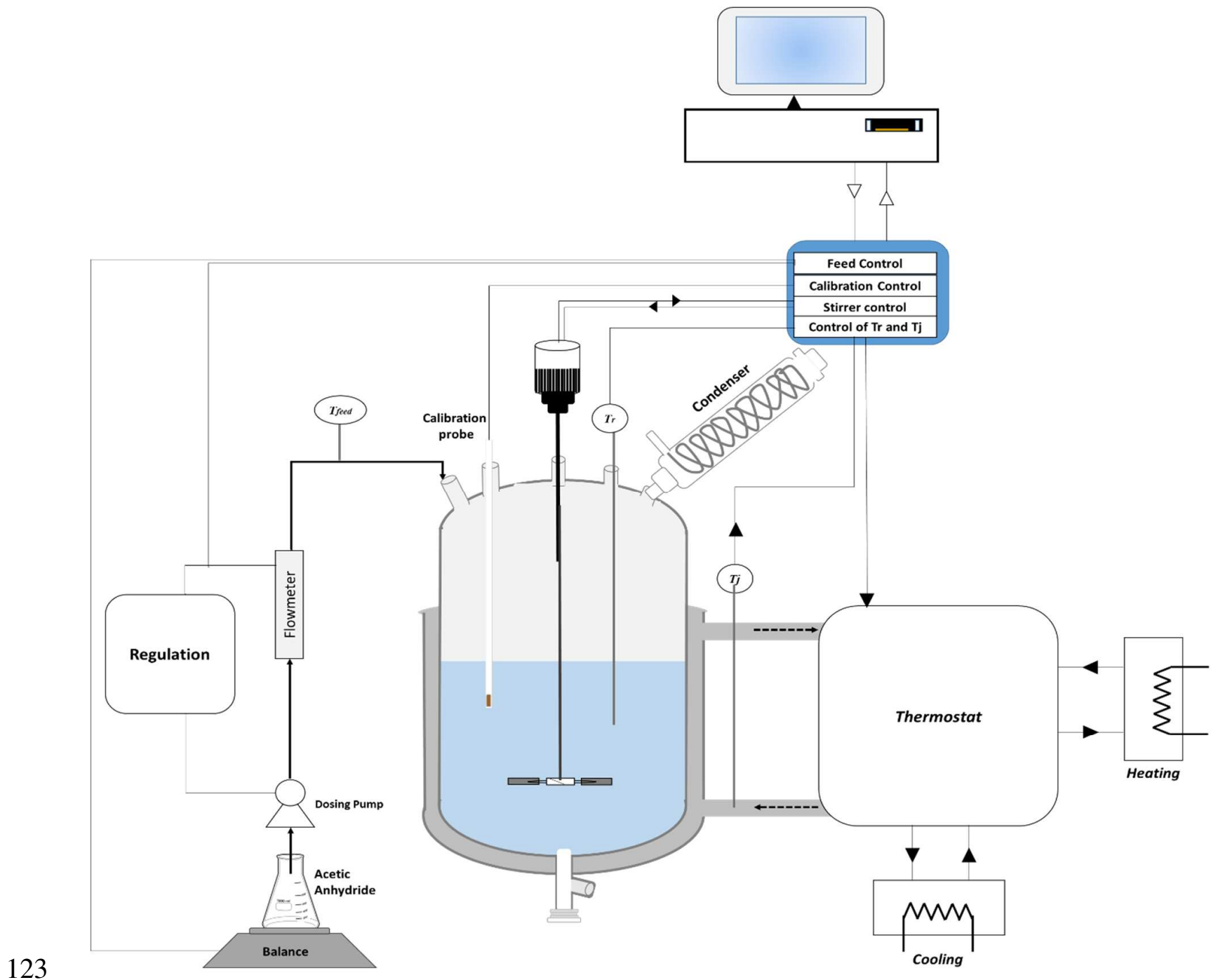

124

Fig. 2. Schematic representation of the reaction calorimeter RC1.

125

126

127

128 
129 Table 2

130 Experimental matrix for acetic anhydride hydrolysis in $\mathrm{RC} 1$ calorimeter with an agitation

131 speed of $400 \mathrm{rpm}$.

132

\begin{tabular}{|c|c|c|c|c|c|c|}
\hline RUN & $\begin{array}{c}\text { Added } \\
\text { volume of } \\
\text { acetic } \\
\text { anhydride } \\
\text { (L) }\end{array}$ & $\begin{array}{c}\text { Time of } \\
\text { addition (s) }\end{array}$ & $\begin{array}{c}\text { Acetic } \\
\text { anhydride } \\
\text { volumetric } \\
\text { flow rate }\left(\mathrm{Ls}^{-1}\right)\end{array}$ & $\begin{array}{c}\text { Initial } \\
\text { volume of } \\
\text { water }(L)\end{array}$ & $\begin{array}{l}\text { Initial jacket } \\
\text { and reaction } \\
\text { temperature } \\
\left.\qquad{ }^{\circ} \mathrm{C}\right)\end{array}$ & $\begin{array}{c}\text { Feed } \\
\text { temperature } \\
\left({ }^{\circ} \mathbf{C}\right)\end{array}$ \\
\hline 6 & 0.2295 & 300 & 0.0007 & 1.2000 & 39.88 & 22.86 \\
\hline 7 & 0.464 & 300 & 0.0015 & 0.9658 & 39.87 & 22.20 \\
\hline
\end{tabular}

133 
136 To take into account the autocatalysis effect of acetic anhydride hydrolysis, the reaction can be

137 divided in two routes: catalyzed and non-catalyzed one. Fig. 3 shows the non-catalyzed 138 reaction mechanism.

1)<smiles>CC(=O)[CH+]OC(C)=O</smiles>

2)<smiles>CC(=O)OC(C)([O-])[OH+]</smiles><smiles>CC(=O)[OH+]C(C)=O</smiles><smiles>C#C[CH+]C(C)=O</smiles>

3)<smiles>CC(=O)[O-]</smiles> 
142 From Fig. 3, the rate-determining step can be assumed to be step 1. Thus, the non-catalyzed 143 hydrolysis rate can be expressed as:

$144 R_{\text {Hydrolysis-non.cat }}=k_{\text {Hydrolysis-non.cat }} \times[$ Anhydride Acetic $] \times\left[\mathrm{H}_{2} \mathrm{O}\right]$

145 Fig. 4 shows the reaction mechanism by the catalyzed route. 
1)

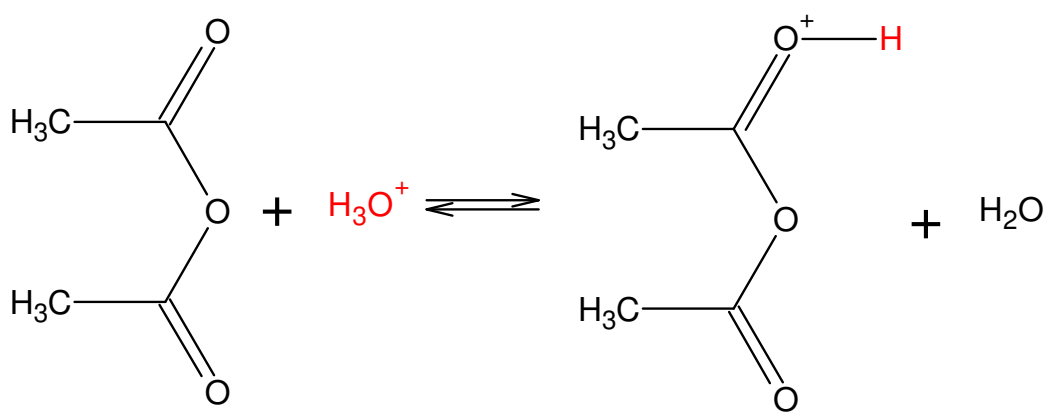

2)<smiles>CC(=O)OC(C)=[OH+]</smiles>

Intermediate 1

Intermediate 1<smiles>CC(=O)OC(C)(O)[OH2+]</smiles>

3)<smiles>CC(=O)OC(C)([OH+])O[Hg]</smiles><smiles>[CH2+]C(C)=[OH+]</smiles>

4)<smiles></smiles>

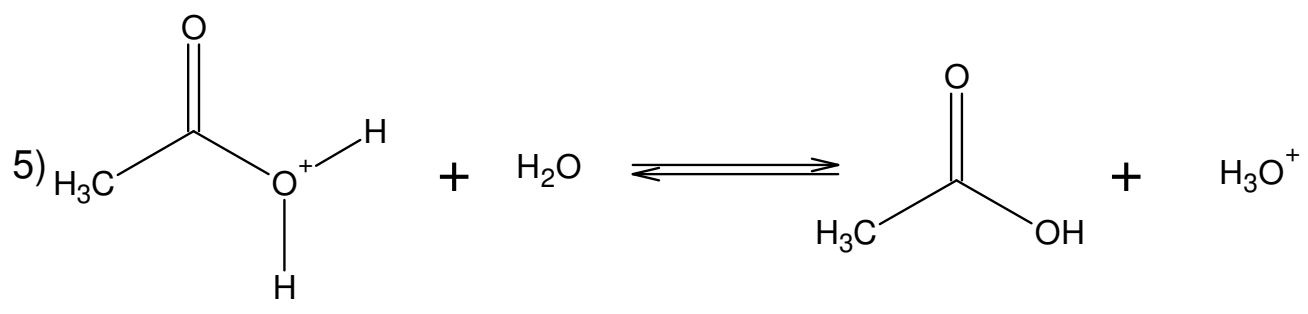

Fig. 4. Catalyzed reaction mechanism. 
148 Reaction 2 (Fig. 4) is assumed to be the rate determining step, thus the rate of catalyzed

149 hydrolysis can be expressed as

$150 R_{\text {Hydrolysis-cat }}=k_{\text {Hydrolysis-cat }} \times\left[\right.$ Intermediate $\left._{1}\right] \times\left[\mathrm{H}_{2} \mathrm{O}\right]$

151 Steady-state approximation is applied on reaction 1 (Fig. 4), thus one gets

$152 \quad K_{1}=\frac{[\text { Intermediate } 1] \times\left[\mathrm{H}_{2} \mathrm{O}\right]}{[\text { Acetic anhydride }] \times\left[\mathrm{H}_{3} \mathrm{O}^{+}\right]}$

153 By combining Eqs (2) and (3), one gets:

$154 \quad R_{\text {Hydrolysis-cat }}=k_{\text {Hydrolysis-cat }} \times K_{1} \times \frac{[\text { Acetic anhydride }] \times\left[\mathrm{H}_{3} \mathrm{O}^{+}\right]}{\left[\mathrm{H}_{2} \mathrm{O}\right]} \times\left[\mathrm{H}_{2} \mathrm{O}\right]$

155 Hence, by adding Eqs (1) and (4), the rate of hydrolysis becomes

$156 \quad R_{\text {Hydrolysis }}=R_{\text {Hydrolysis-non.cat }}+R_{\text {Hydrolysis-cat }}$

$157=\left([\right.$ Acetic anhydride $\left.] \times\left[\mathrm{H}_{2} \mathrm{O}\right]\right) \times\left[k_{\text {Hydrolysis-non.cat }}+k_{\mathrm{Hydrolysis}-\mathrm{cat}} \times K_{1} \times \frac{\left[\mathrm{H}_{3} \mathrm{O}^{+}\right]}{\left[\mathrm{H}_{2} \mathrm{O}\right]}\right](5)$

158 By noting $k_{H y d r o l y s i s-c a t}^{\prime}=k_{H y d r o l y s i s-c a t} \times K_{1}$, then eq (5) becomes

159

$R_{\text {Hydrolysis }}=\left([\right.$ Acetic anhydride $\left.] \times\left[\mathrm{H}_{2} \mathrm{O}\right]\right) \times\left[k_{\text {Hydrolysis-non.cat }}+k_{\text {Hydrolysis-cat }}^{\prime} \frac{\left[\mathrm{H}_{3} \mathrm{O}^{+}\right]}{\left[\mathrm{H}_{2} \mathrm{O}\right]}\right]$

$160 \quad(6)$

161 Both rate constants were estimated in this study.

162

163

164 
166 The autoprotolysis of water was neglected in this study. The source of hydroxonium ion was 167 mainly due to the dissociation of the product acetic acid as illustrated by Scheme 1.

168

170

171 Mass balance of the organic species gives

$172[\text { Acetic anhydride }]_{F E E D}=[$ Acetic anhydride $]+\frac{1}{2} \cdot[$ Acetic acid $]+\frac{1}{2} \cdot\left[\mathrm{CH}_{3} \mathrm{COO}^{-}\right]$

173 The dissociation of acetic acid is fast, thus the dissociation constant, $K_{\text {Acetic acid }}^{C}$, can be 174 expressed as

$175 K_{\text {Acetic acid }}^{C}=\frac{\left[\mathrm{CH}_{3} \mathrm{COO}^{-}\right] \times\left[\mathrm{H}_{3} \mathrm{O}^{+}\right]}{\left[\mathrm{CH}_{3} \mathrm{COOH}\right] \times\left[\mathrm{H}_{2} \mathrm{O}\right]}=\frac{K_{\text {Acetic acid }}^{T}}{55.56}$

$176 K_{\text {Acetic acid }}^{T}$ is the true thermodynamic constant expressed according to Sue et al. [31].

177 According to the electroneutrality principle, the concentration of cation and anion species are 178 the same.

$179\left[\mathrm{H}_{3} \mathrm{O}^{+}\right] \approx\left[\mathrm{CH}_{3} \mathrm{COO}^{-}\right]$

180 By combining Eqs (8) and (9), the acetic acid concentration can be expressed as

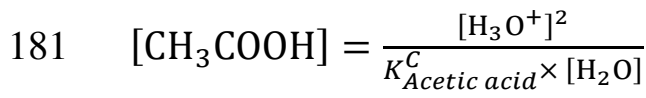


182 Eqs (10) and (9) are introduced in Eq (7) leading to

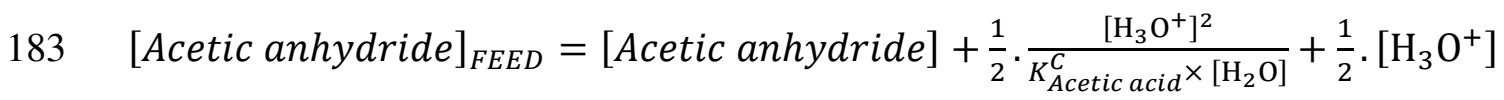

184 equivalent to

$185 \frac{1}{2} \cdot \frac{\left[\mathrm{H}_{3} \mathrm{O}^{+}\right]^{2}}{K_{\text {Acetic acid }}^{C} \times\left[\mathrm{H}_{2} \mathrm{O}\right]}+\frac{1}{2} \cdot\left[\mathrm{H}_{3} \mathrm{O}^{+}\right]+[$Acetic anhydride $]-[\text {Acetic anhydride }]_{F E E D}=0$

186

(11)

187 By taking into account only the positive roots of Eq (11), one gets

$188\left[\mathrm{H}_{3} \mathrm{O}^{+}\right]=K_{\text {Acetic acid }}^{C} \cdot\left[\mathrm{H}_{2} \mathrm{O}\right] \cdot\left[-\frac{1}{2}+\sqrt{\frac{1}{4}-\frac{2}{K_{\text {Acetic acid }}^{C} \times\left[\mathrm{H}_{2} \mathrm{O}\right]} \cdot\left([\text { Acetic anhydride }]-[\text { Acetic anhydride }]_{F E E D}\right)}\right]$

190

191

192

193

194

195

196 
198 As mentioned in the experimental section, experiments were performed in semi-batch mode

199 with the addition of acetic anhydride in the reactor.

200 Mass balances for acetic anhydride, acetic acid and water lead to the following ordinary

201 differential equations:

$202 \frac{d[\text { Acetic anhydride }]}{d t}=\frac{Q}{V_{R}} \times\left([\text { Acetic anhydride }]_{F E E D}-[\right.$ Acetic anhydride $\left.]\right)-R_{H y d r o l y s i s}$

$203 \quad(13)$

$204 \frac{d[\text { Water }]}{d t}=-[$ Water $] \times \frac{Q}{V_{R}}-R_{\text {Hydrolysis }}$

$205 \frac{d[\text { Acetic acid }]}{d t}=-[$ Acetic acid $] \times \frac{Q}{V_{R}}+2 \times R_{H y d r o l y s i s}$

$206 \frac{d V_{R}}{d t}=Q$

207 where, $\mathrm{Q}$ is the volumetric flow rate, $[\text { Acetic anhydride }]_{F E E D}$ is the concentration of acetic 208 anhydride in the feed. 
213 For a semi-batch reactor under isoperibolic conditions, energy balance on the reaction mixture 214 phase can be expressed as [28,32]:

$$
\mathrm{q}_{\text {acc }}=\mathrm{q}_{\text {reaction }}+\mathrm{q}_{\text {exchange with heat carrier }}+\mathrm{q}_{\text {loss }}+\mathrm{q}_{\text {dosing }}+\mathrm{q}_{\text {solvation }}
$$

$\Leftrightarrow\left(\mathrm{m}_{R} \cdot \widehat{{C_{P_{R}}}_{1}}+\mathrm{m}_{\text {ins }} \cdot \widehat{C_{P_{\text {lns }}}}\right) \times \frac{d T_{R}}{d t}=-R_{\text {Hydrolysis }} \times V_{R} \times \Delta H_{R, \text { Hydrolysis }}+U \times A \times$

$\left(T_{j}-T_{R}\right)+U A_{\text {loss }} \times\left(T_{\text {ambient }}-T_{R}\right)+Q \times \overline{C_{P_{\text {Acetic Anhydride }}}} \times[\text { Acetic anhydride }]_{\text {FEED }} \times$

$\left(T_{\text {FEED }}-T_{R}\right)-\frac{\Delta H_{\text {solvation }} \times Q}{V_{\text {molar }} \times(\text { Acetic Anhydride })}$

220 Heat capacities of the different species at stake were estimated by using Aspen Plus and the

221 UNIQUAC thermodynamic model. Each term of Eq (17) is explained below.

$222 *$ Accumulated heat-flow rate $\mathrm{q}_{a c c}=\left(\mathrm{m}_{R} \cdot \widehat{C_{P_{R}}}+\mathrm{m}_{\text {ins }} \cdot \widehat{C_{P_{\text {lns }}}}\right) \times \frac{d T_{R}}{d t}$

223 The specific heat capacity of the reaction mixture $\hat{C}_{P_{R}}\left(\mathrm{~J}_{\mathrm{kg}}{ }^{-1} \cdot \mathrm{K}^{-1}\right)$ can be expressed as

$$
\hat{C}_{P_{R}}=\omega_{W} \times \hat{C}_{P_{W}}+\omega_{\text {Acetic anhydride }} \times \hat{C}_{P_{\text {Acetic anhydride }}}+\omega_{\text {Acetic acid }} \times \hat{C}_{P_{\text {Acetic acid }}}
$$

The specific heat capacity of a compound with temperature can be expressed as

$\frac{\hat{C}_{P_{i}}(T)}{\hat{C}_{P_{i}}\left(T_{R e f}\right)}=A \cdot T^{2}+B . T+C$

228 Fig. 5 shows the evolution of $\frac{\hat{C}_{P_{i}}(T)}{\hat{C}_{P_{i}}\left(T_{R e f=313.15 K}\right)}$ for water, acetic anhydride and acetic acid based on AspenPlus database. 


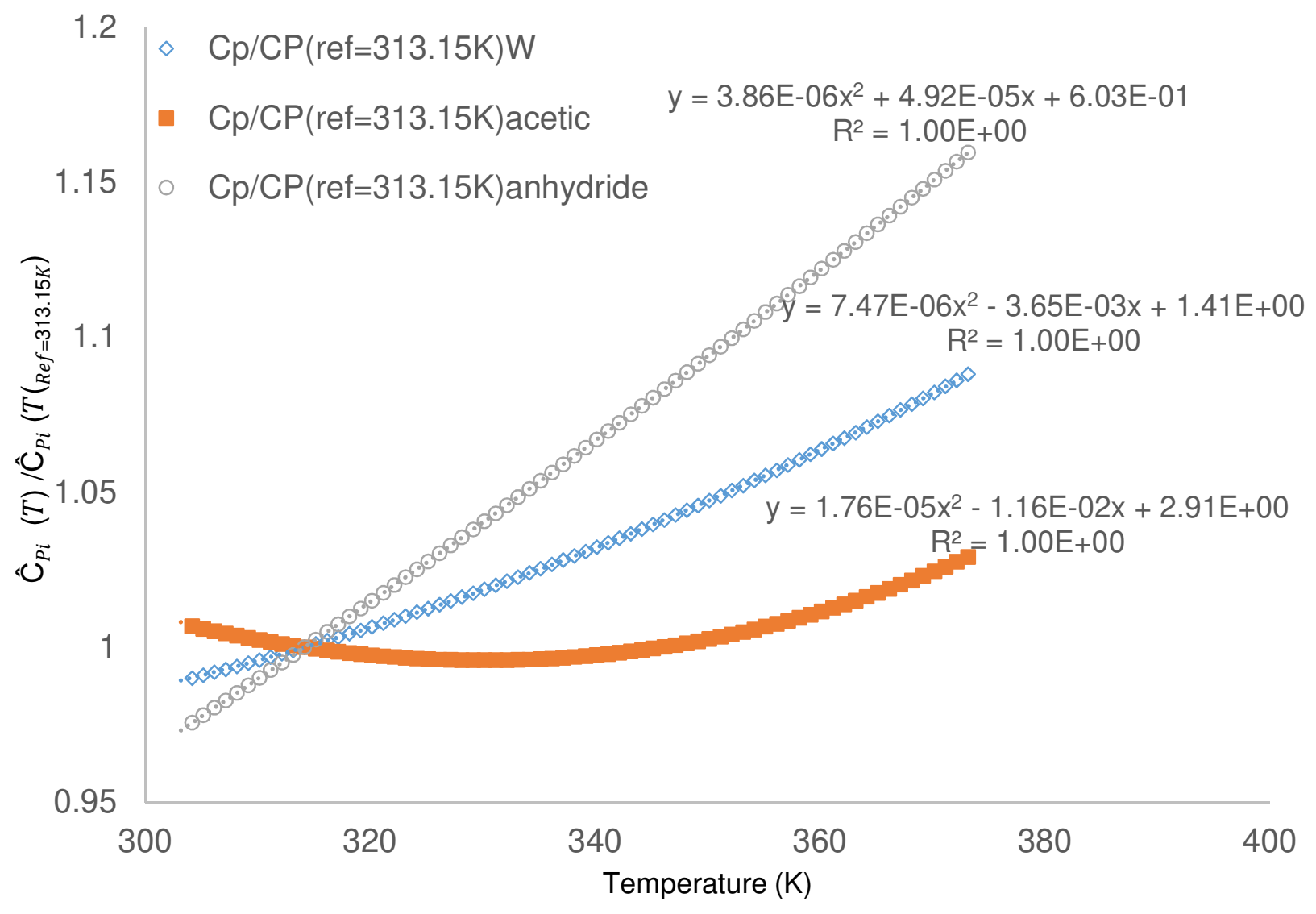
Fig. 5. $\frac{\widehat{C}_{P_{i}}(T)}{\widehat{C}_{P_{i}}\left(T_{R e f=313.15 K}\right)}$ versus temperature $\mathrm{T} / \mathrm{K}$.

\section{Table 3}

235 Specific heat capacity parameters.

236

\begin{tabular}{cccc}
\hline & Water & Acetic acid & Acetic anhydride \\
\cline { 2 - 4 } $\mathbf{C p}(\mathbf{3 1 3 . 1 5 K})$ & 4.18008 & 1.33385 & 1.63724 \\
$\mathbf{A}$ & $7.47 \mathrm{E}-06$ & $1.76 \cdot 10^{-05}$ & $3.86 \cdot 10^{-06}$ \\
$\mathbf{B}$ & -0.0036 & -0.0116 & $5.00 \cdot 10^{-0}$ \\
$\mathbf{C}$ & 1.4081 & 2.911 & 0.6032 \\
\hline
\end{tabular}


237 The evaluation of the term $\mathrm{m}_{\text {ins }} . \widehat{C_{P_{l n s}}}$ is detailed in chapter 3.5. Reactor characteristic.

$238 *$ Heat-flow rate due to chemical reaction $\mathrm{q}_{\text {reaction }}=-R_{\text {Hydrolysis }} \times V_{R} \times \Delta H_{R, \text { Hydrolysis }}$

239 From Zogg et al. [24], the enthalpy of hydrolysis, $\Delta H_{R, H y d r o l y s i s}$, can be estimated to be equal 240 to $-60 \mathrm{~kJ} / \mathrm{mol}$. The term $V_{R}$ stands for the reaction volume.

$241 *$ Heat-flow rate exchange with heat carrier $\mathrm{q}_{\text {exchange with heat carrier }}=U \times A \times\left(T_{j}-T_{R}\right)$

242 In chapter 3.5, the determination of $U$ and $A$ is explained. The terms $T_{j}$ and $T_{R}$ are the jacket 243 and reaction temperatures, respectively.

$244 *$ Heat flow rate loss $\mathrm{q}_{\text {loss }}=U A_{\text {loss }} \times\left(T_{\text {ambient }}-T_{R}\right)$

245 The estimation of this loss is explained in chapter 3.5.

$246 *$ Heat flow rate due to dosing $\mathrm{q}_{\text {dosing }}=Q \times \overline{C_{P_{\text {Acetc Anhydride }}}} \times[\text { Acetic anhydride }]_{F E E D} \times\left(T_{F E E D}-T_{R}\right)$

247 where, $\overline{C_{P_{\text {Acetic Anhydride }}}}\left(\mathrm{J} \mathrm{mol}^{-1} \mathrm{~K}^{-1}\right)$ is the molar heat capacity of acetic anhydride. The 248 concentration of acetic anhydride in the feed is $[\text { Acetic anhydride }]_{F E E D}=10.58$ mol. $L^{-1}$. 249 The term $\mathrm{Q}$ is the feeding volumetric flow-rate.

$250 *$ Heat flow rate of solvation $\mathrm{q}_{\text {solvation }}=-\frac{\Delta H_{\text {solvation }} \times Q}{V_{\text {molar }} x(\text { Acetic Anhydride })}$

251 From Zogg et al. [24], the heat of solvation of acetic anhydride $\Delta H_{\text {solvation }}$ is equal to +3000 $252 \mathrm{~J} / \mathrm{mol}$ when the reaction temperature is higher than $40^{\circ} \mathrm{C}$. The molar volume of acetic 253 anhydride is equal to $0.0944 \mathrm{~L} \mathrm{~mol}^{-1}$ [33]. 
256 The relationship between the reaction volume and the surface A was found to be

$257 \quad \mathrm{~A}\left(m^{2}\right)=0.0817 \times V(L)$

258 To evaluate the heat transfer coefficient $U$ during the reaction, one can use the sum of thermal

259 resistances using the thin wall approximation [34-35] .

$260 \quad \frac{1}{U}=\frac{1}{h_{R}}+\frac{d_{\text {Wall }}}{\lambda_{\text {Wall }}}+\frac{1}{h_{j}}$

261 where, $\frac{1}{h_{R}}$ and $\frac{1}{h_{j}}$ represent the convective resistance to the heat transfer from the reaction side

262 and jacket side, respectively; $d_{w}$ is the thickness of the glass wall between reaction mixture and 263 the heat carrier fluid, and $\lambda_{\text {wall }}$ is the heat conductivity of the glass wall.

264 The term $\frac{1}{h_{R}}$ can change during the reaction, and the term $\frac{d_{\text {Wall }}}{\lambda_{\text {Wall }}}+\frac{1}{h_{j}}$ can be merged to a 265 constant and noted by $\frac{1}{\varphi_{R}}$. Eq. (22) becomes now:

$266 \quad \frac{1}{U}=\frac{1}{h_{R}}+\frac{1}{\varphi_{R}}$

267 Under isothermal conditions and in the absence of chemical reactions, the properties of the

268 fluid and geometrical factors are constant. Thus the internal heat transfer coefficient can be 269 expressed as

$\frac{1}{h_{R}}=$ Const $\times\left(\frac{\mu_{R}}{\rho_{R}^{2} \times \hat{C}_{P_{R}} \times \lambda_{R}^{2}}\right)^{1 / 3} \times\left(\frac{d_{R}^{3}}{d_{S}^{2}}\right)^{1 / 3} \times\left(\frac{1}{N^{2}}\right)^{1 / 3}$

271 where, 
$273 \mu_{R}$ is the dynamic viscosity of the reaction mixture in $\mathrm{kg} \mathrm{m}^{-1} \mathrm{~s}^{-1}$,

$274 \rho_{R}$ is the density of the reaction mixture in $\mathrm{kg} \mathrm{m}^{-3}$,

$275 \widehat{\mathrm{C}}_{P_{R}}$ is the specific heat capacity of the reaction mixture in $\mathrm{J} \mathrm{kg}^{-1} \mathrm{~K}^{-1}$,

$276 \lambda_{R}$ is the thermal conductivity of the reaction mixture in $\mathrm{W} \mathrm{m}^{-1} \mathrm{~K}^{-1}$,

$277 \mathrm{~d}_{R}$ is the reactor diameter in $\mathrm{m}$,

$278 \mathrm{~N}$ is the rotating speed in round per second,

$279 \mathrm{~d}_{s}$ is the stirrer diameter in $\mathrm{m}$.

280 Fig. 6 shows the evolution of $\frac{1}{U}$ versus $\left(\frac{1}{N^{2}}\right)^{1 / 3}$, also known as Wilson plot. To evaluate the

281 values of $\frac{1}{\varphi_{R}}$ and $\frac{1}{h_{R}}$, a mixture containing $56 \mathrm{wt} \%$ of acetic acid was used as a representative 282 one. 


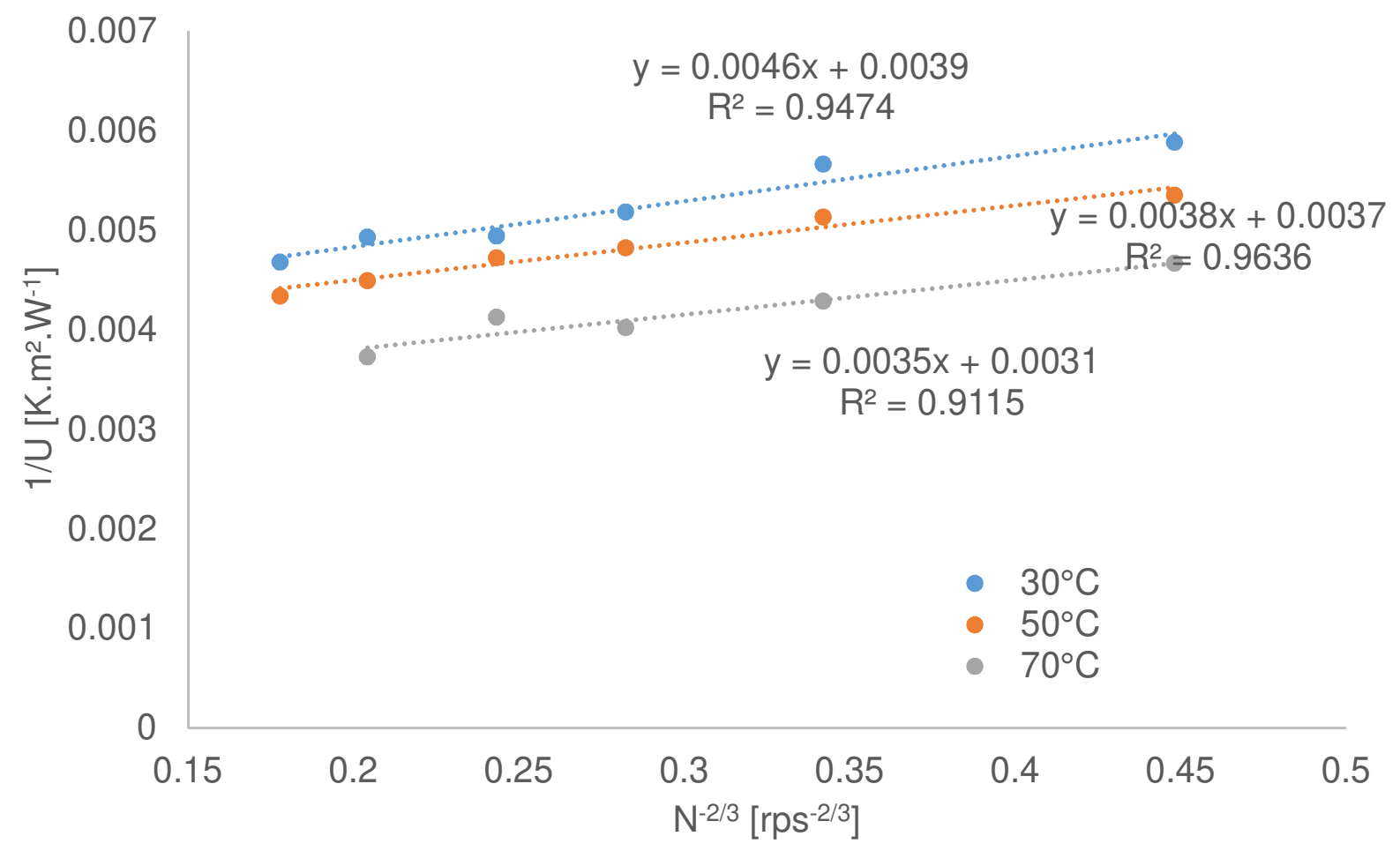

Fig. 6. Wilson plot $1 / \mathrm{U}$ versus $\mathrm{N}^{-2 / 3}$ with a weight percentage of acetic acid of $56 \%$.

286 From Fig. 6, the values of $\frac{1}{\varphi_{R}}$ and $\frac{1}{h_{R}}$ can be assumed temperature independent. The values of $287 \frac{1}{\varphi_{R}}$ is evaluated to $0.0035 \mathrm{~K} \mathrm{~m}^{2} \mathrm{~W}^{-1}$ and $\frac{1}{h_{R}}$ to $0.0011 \mathrm{~K} \mathrm{~m}^{2} \mathrm{~W}^{-1}$ at $400 \mathrm{rpm}$. 
290 In the absence of chemical reactions, the energy balance can be expressed as

$291\left(\mathrm{~m}_{R} \cdot \widehat{C_{P_{R}}}+\mathrm{m}_{\text {ins }} \cdot \widehat{C_{P_{\text {lns }}}}\right) \times \frac{d T_{R}}{d t}=U \times A \times\left(T_{j}-T_{R}\right)$

292 By assuming that specific heat capacity is constant on small temperature range, thus Eq. (26)

293 can be integrated as

$294 \ln \frac{T_{R}-T_{j}}{T_{R 0}-T_{j 0}}=\frac{-U \times A}{\left(\mathrm{~m}_{R} \cdot \widehat{C_{P_{R}}}+\mathrm{m}_{\text {ins }} \cdot \widehat{P_{P_{l n s}}}\right)} \times t$

295 The term $\mathrm{m}_{\text {ins }} . \widehat{C_{P_{\text {Ins }}}}$ was equal to $29.95 \mathrm{~J} \mathrm{~K}^{-1}$.

296 *Determination of the heat loss qloss

297 Heat losses may then occur on the top side and on lateral or jacket side. Assuming a same heat

298 loss coefficient on both sides, since heat losses are limited by external natural convection on

299 both areas, the energy balance can then be described by

300

$\left(\mathrm{m}_{R} \cdot \widehat{C_{P_{R}}}+\mathrm{m}_{\text {ins }} \cdot \widehat{C_{P_{\text {lns }}}}\right) \times \frac{d T_{R}}{d t}=U A_{\text {loss }} \times\left(T_{\text {ambient }}-T_{R}\right)$

301 By assuming that heat capacity and $\mathrm{UA}_{\text {loss }}$ is temperature independent, thus Eq. (28) becomes

302

$\ln \frac{T_{R}-T_{\text {ambiant }}}{T_{R 0}-T_{\text {ambianto }}}=\frac{-U A_{\text {loss }}}{\left(\mathrm{m}_{R} \cdot \widehat{C_{P_{R}}}+\mathrm{m}_{\text {ins }} \cdot \widehat{C_{P_{\text {lns }}}}\right)} \times t$

303 We have found that $\mathrm{UA}_{\text {loss }}$ is equal to $0.053 \mathrm{~W} \mathrm{~K}^{-1}$. 
306 The system of ordinary differential Eqs (13)-(17) were solved out by the ODESSA solver.

307 Reaction temperature was used as an observable.

308 Simplex ad Levenberg-Marquardt algorithms were used to estimate the kinetic constants

$309\left(k_{\text {Hydrolysis-cat }}^{\prime}\left(T_{\text {ref }}\right) ; E a_{\text {Hydrolysis-cat }} ; k_{H y d r o l y s i s-n o n . c a t}\left(T_{\text {ref }}\right)\right.$ and Ea $a_{\text {Hydrolysis-non.cat }}$.

310 The rate constants at a temperature $\mathrm{T}$ were estimated by using a modified Arrhenius equation:

$311 k_{\text {Hydrolysis-cat }}^{\prime}(T)=k_{\text {Hydrolysis-cat }}^{\prime}\left(T_{\text {ref }}\right) \times \exp \left(\frac{-E a_{\text {Hydrolysis-cat }}}{R} \times\left(\frac{1}{T}-\frac{1}{T_{\text {ref }}}\right)\right)$

$312 k_{\text {Hydrolysis-non.cat }}(T)=k_{\text {Hydrolysis-non.cat }}\left(T_{\text {ref }}\right) \times \exp \left(\frac{-E a_{\text {Hydrolysis-non.cat }}}{R} \times\left(\frac{1}{T}-\frac{1}{T_{\text {ref }}}\right)\right)$

314 The solver and algorithms were implemented in the software ModEst [36]. The optimization

315 algorithms minimized the following objective function $\omega$

$316 \omega=\left(y_{\text {exp }}-y_{\text {model }}\right)^{2}$

317 The coefficient of determination was expressed as

$318 \quad R^{2}=1-\frac{\left(y_{i}-\hat{y}_{i}\right)^{2}}{\left(y_{i}-\bar{y}\right)^{2}}$ 
321 Figs. 7-8 show the fitting of the model to the experimental data for Runs 5 and 4 . One can 322 notice that the model fits the experimental data. The value of the coefficient of determination 323 was found to be $99.15 \%$. The reliability of the developed model is confirmed by the parity plot 324 (Fig. 9).

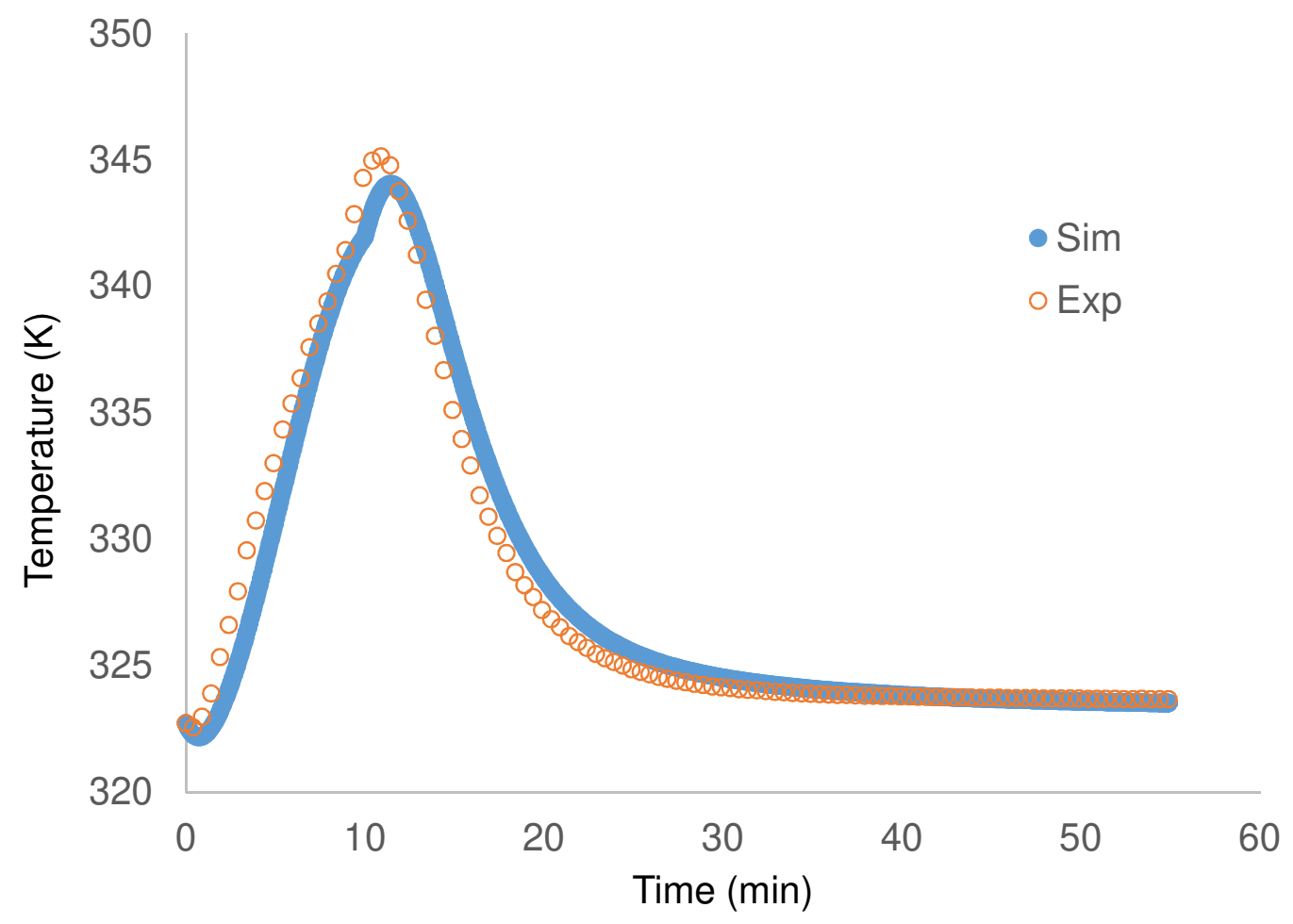

325

Fig. 7. Fitting of the model to the experimental data for Run 5. 


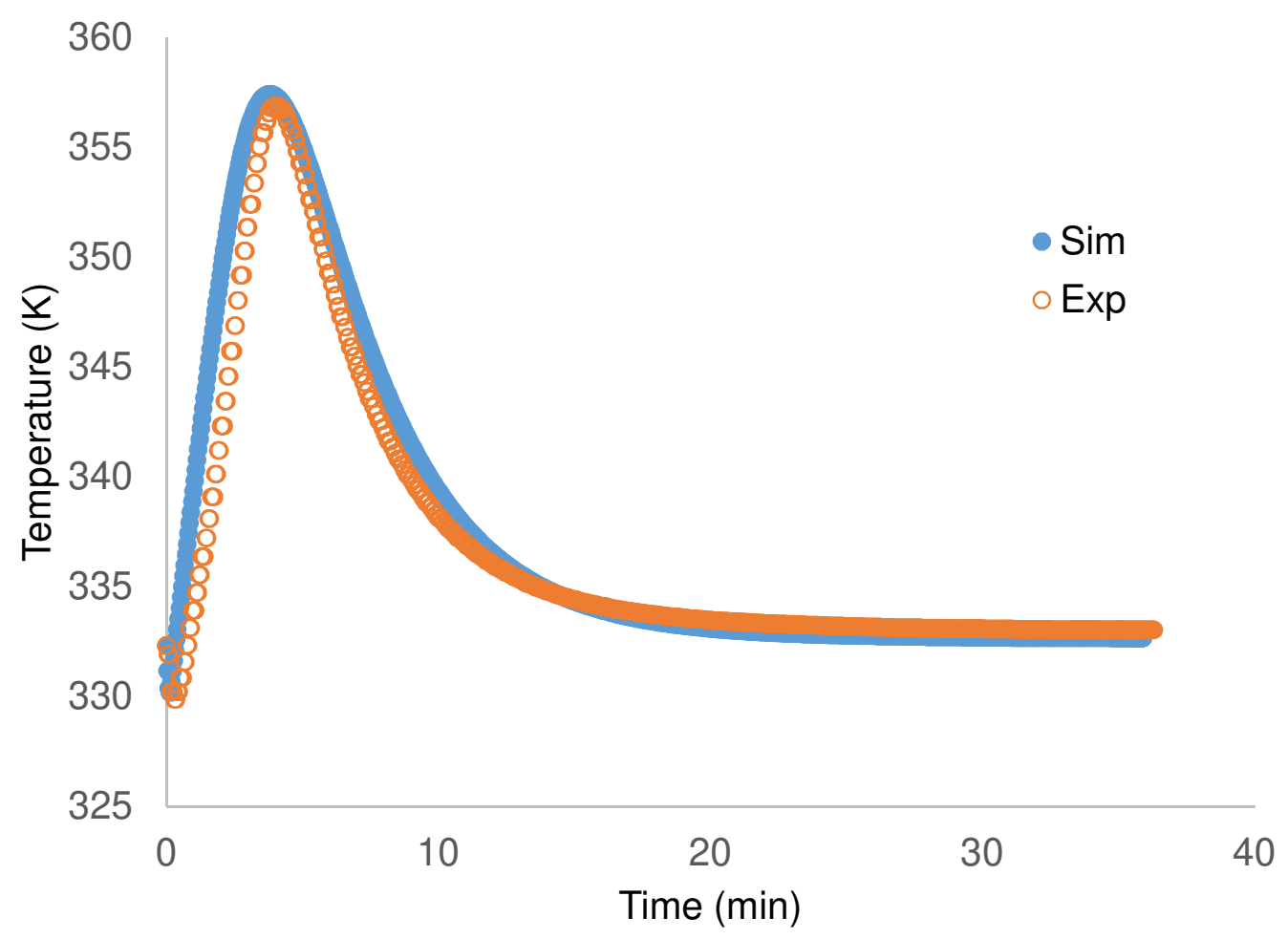

Fig. 8. Fitting of the model to the experimental data for Run 4. 


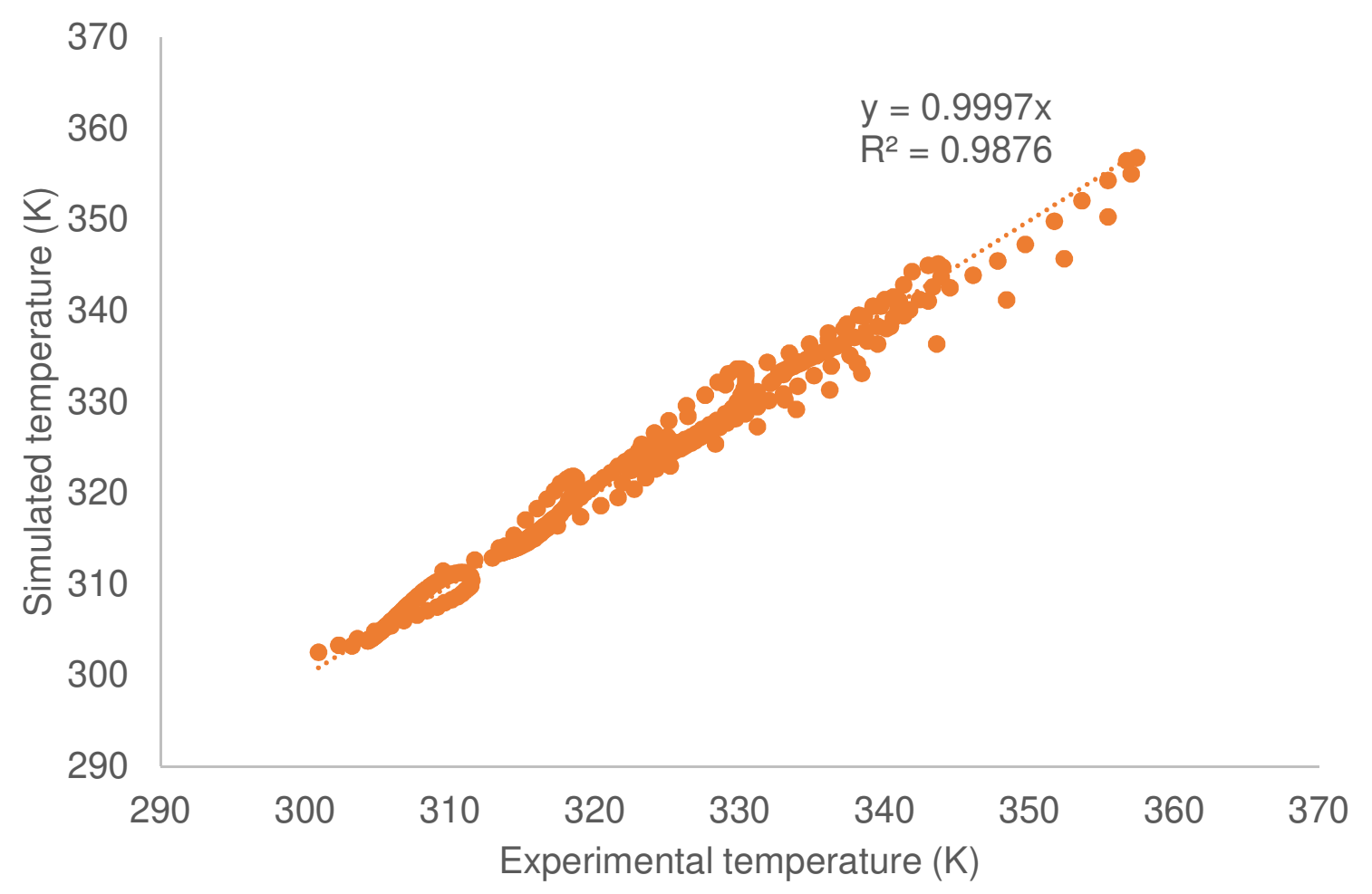

Fig. 9. Parity plot.

333 Table 4 shows the values of the estimated kinetic constants for both routes. One can notice that

334 the standard deviation values are very low for the non-catalyzed route but higher for the 335 catalyzed ones. This difference can be explained by the fact that the reaction mechanism might 336 be more complex that the one derived. Nevertheless, these standard error values are acceptable.

337 As expected, activation energy for the catalyzed route is lower than for the non-catalyzed one.

338 One should keep in mind that the rate constant for the catalyzed routes was lumped with an 339 equilibrium constant.

340 A direct comparison with the other kinetic model, displayed in Table 5, cannot be done

341 because the expression of reaction rate was not the same. Zogg et al. [25] proposed a first order 342 reaction rate with respect to acetic anhydride and did not take into account the autocatalytic 
343 effect, neither the catalytic effect of hydrochloric acid. The kinetic constants for the non-

344 catalytic phenomenon estimated in this work can be compared with the ones obtained from

345 References [20], [22] and [23] by keeping in mind that in these references the autocatalytic

346 effect was not taken into account.

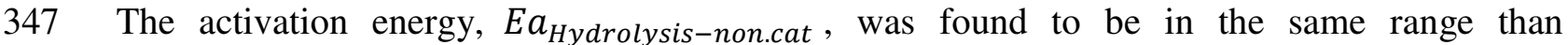

348 References [20] and [22] but lower than the one estimated in Reference [25]. The rate

349 constants at $40^{\circ} \mathrm{C}$ was calculated to be: $\mathrm{k}\left(40^{\circ} \mathrm{C}\right)=2.23 \cdot 10^{-4} \mathrm{~L} \mathrm{~mol}^{-1} \mathrm{~s}^{-1}$ for [20], $\mathrm{k}\left(40^{\circ} \mathrm{C}\right)=$

$3502.85 \cdot 10^{-5} \mathrm{~L} \mathrm{~mol}^{-1} \mathrm{~s}^{-1}$ for [23] and $\mathrm{k}\left(40^{\circ} \mathrm{C}\right)=6.60 \cdot 10^{-5} \mathrm{~L} \mathrm{~mol}^{-1} \mathrm{~s}^{-1}$ for [22]. Hence, the kinetic

351 constants for the non-catalytic effect estimated in this work are closer to the ones estimated by

352 Susanne et al. [22].

353 Table 4

354 Estimated kinetic constants with $\mathbf{T}_{\text {ref }}=\mathbf{3 1 3 . 1 5 K}$.

\begin{tabular}{cccc}
\hline Kinetic constants & Units & Estimated Parameters & Standard Error \% \\
\hline$k_{\text {Hydrolysis-cat }}^{\prime}\left(T_{\text {ref }}\right)$ & $\mathrm{L} \mathrm{mol}^{-1} \mathrm{~s}^{-1}$ & $0.983 \cdot 10^{-1}$ & 17.9 \\
$E a_{\text {Hydrolysis-cat }}$ & $\mathrm{J} \mathrm{mol}^{-1}$ & 29700 & 25.4 \\
$k_{\text {Hydrolysis-non.cat }}\left(T_{\text {ref }}\right)$ & $\mathrm{L} \mathrm{mol}^{-1} \mathrm{~s}^{-1}$ & $0.250 \cdot 10^{-04}$ & 4.6 \\
$E a_{\text {Hydrolysis-non.cat }}$ & $\mathrm{J} \mathrm{mol}^{-1}$ & 46000 & 4.3 \\
\hline
\end{tabular}

355

356

357

358 
Table 5

361 Kinetic constants reported in the literature.

\begin{tabular}{|c|c|c|c|c|}
\hline Reference & Added catalyst & Reaction rate & $\mathrm{k}\left(\mathrm{s}^{-1}\right)$ at $40^{\circ} \mathrm{C}$ & $\mathrm{Ea}\left(\mathrm{kJ} \mathrm{\textrm {mol } ^ { - 1 } )}\right.$ \\
\hline \multirow[t]{2}{*}{ Zogg et al. [25] } & $\mathrm{HCl}$ & $k(T) \times[$ Acetic anhydride $]$ & $8.20 \cdot 10^{-03}$ & 56 \\
\hline & & & $A\left(L\right.$ mol$\left.^{-1} \mathbf{s}^{-1}\right)$ & $\mathbf{E a}\left(\mathrm{kJmol}^{-1}\right)$ \\
\hline Asprey et al. [20] & None & $A \times e^{\frac{-E a}{R \cdot T}} \times\left([\right.$ Acetic anhydride $\left.] \times\left[H_{2} \mathrm{O}\right]\right)$ & 2121.75 & 41.84 \\
\hline Hirota et al. [23] & None & $A \times e^{\frac{-E a}{R \cdot T}} \times\left([\right.$ Acetic anhydride $\left.] \times\left[\mathrm{H}_{2} \mathrm{O}\right]\right)$ & 19842433.99 & 71 \\
\hline \multicolumn{5}{|l|}{ Susanne et al. } \\
\hline$[22]$ & None & $A \times e^{\frac{-E a}{R \cdot T}} \times\left([\right.$ Acetic anhydride $\left.] \times\left[H_{2} O\right]\right)$ & 3133.79 & 46.02 \\
\hline
\end{tabular}

362

363 Another interesting comparison is between the kinetics of water and acetic anhydride,

364 methanol and acetic anhydride. Wei et al. [37] developed a kinetic model for the esterification

365 of acetic anhydride and methanol by taking into account the side reactions of acetic acid

366 esterification by methanol and acetic anhydride hydrolysis. They found that the activation

367 energy for the reaction between acetic anhydride and methanol is $88.07 \mathrm{~kJ} \mathrm{~mol}^{-1}$, which is

368 higher than the one between water and acetic anhydride. Hence, the nucleophilic attack by

369 water is faster than by methanol. 
374 3.7. Validation of the model with RC1

375 Similar experiments were performed in RC1 in order to compare the estimated constant in an 376 established calorimeter. The use of RC1 calorimeter system allows to have the evolution of qloss, $\mathrm{C} \mathrm{p}_{\mathrm{R}}$ and UA with time.

378 The coefficient of determination was found to be $93.44 \%$, which is slightly lower than the 379 previous one.

380 Table 6 shows that the estimated kinetics are similar than the one obtained in handmade

381 reactor, showing the reliability of this latter system.

383 Estimated kinetic constants with $\mathrm{RC} 1$ and $\mathrm{T}_{\mathrm{ref}}=313.15 \mathrm{~K}$.

384

\begin{tabular}{cccc}
\hline Kinetic constants & Units & Estimated parameter & Standard error \% \\
\hline$k_{\text {Hydrolysis-cat }}^{\prime}\left(T_{\text {ref }}\right)$ & $\mathrm{L} \mathrm{mol}^{-1} \mathrm{~s}^{-1}$ & 0.105 & 29.2 \\
$E a_{\text {Hydrolysis-cat }}$ & $\mathrm{J} \mathrm{mol}^{-1}$ & 29600 & 45.3 \\
$k_{\text {Hydrolysis-non.cat }}\left(T_{\text {ref }}\right)$ & $\mathrm{L} \mathrm{mol}^{-1} \mathrm{~s}^{-1}$ & $0.279 \cdot 10^{-04}$ & 5.0 \\
Ea $a_{\text {Hydrolysis-non.cat }}$ & $\mathrm{J} \mathrm{mol}^{-1}$ & 42100 & 11.0
\end{tabular}

385

386 Fig. 10 shows the fitting of experimental temperature by the simulation for Run 7. 


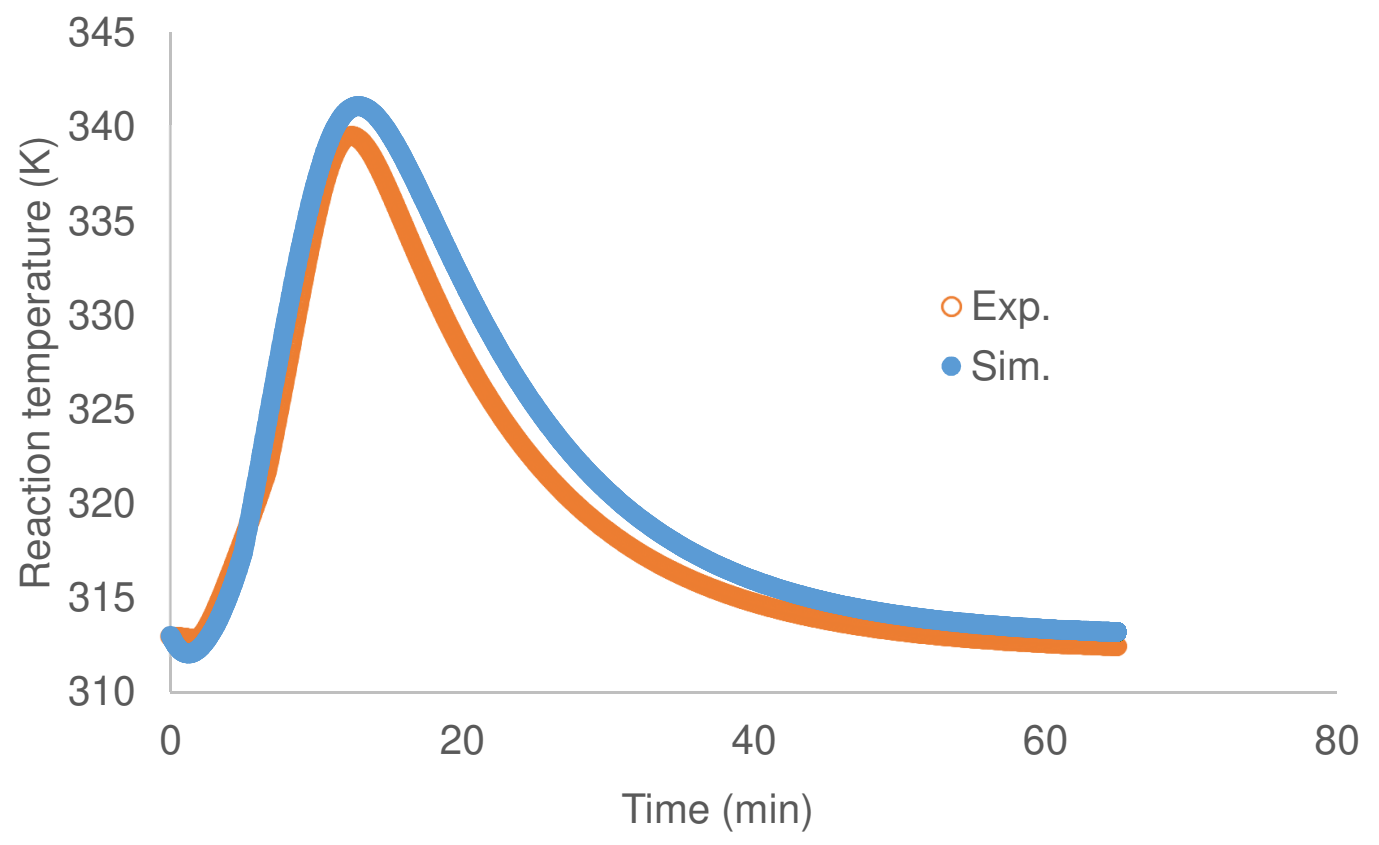

391

392

Fig. 10. Fitting of the model to the experimental data for Run 7.

393

394

395

396 


\section{CONCLUSIONS}

398 This study proposes a revisited kinetic study of the hydrolysis of acetic anhydride by using temperature as an online signal.

400

401

402

403

404

405

406

407

408

409

410

411

412

413

414

415

416

A hand-made calorimeter was thermally characterized to be able to evaluate the heat transfer coefficient, specific heat capacity of the inserts and heat loss. Kinetic experiments were performed under isoperibolic and semibatch mode. To develop a kinetic model, the following parameters were varied: time of addition, initial reaction temperature and amount of acetic anhydride added into the reactor.

The kinetic model, using the handmade calorimeter, was developed by taking into account two routes: non-catalyzed and the catalyzed reaction due to the dissociation of the product acetic acid. The following thermal phenomena were also included: reaction enthalpy, mixing enthalpies and heat loss. It was found that the activation energy of the catalyzed route is lower than the non-catalyzed one.

To validate the results found in handmade calorimeter, experiments were performed in RC1. The estimated kinetic constants in RC1 were similar to the one in the handmade calorimeter. 
$\bar{C}_{P}$

[i]

$\hat{\mathrm{C}}_{\mathrm{P}}$

d

Ea

$\mathrm{k}$

K

$\mathrm{K}^{\mathrm{C}}$

$\mathrm{K}^{\mathrm{T}}$

$\mathrm{m}$

$\mathrm{N}$

Q

$q_{\mathrm{acc}}$

$q_{\text {dosing }}$

qexchange with heat carrier

$q_{\text {loss }}$
Capacity per mol, $\mathrm{J} \mathrm{mol}^{-1} \mathrm{~K}^{-1}$

Concentration of compound $i$

Capacity per mass, $\mathrm{J} \mathrm{g}^{-1} \mathrm{~K}^{-1}$

Diameter, $\mathrm{m}$

Activation energy, $\mathrm{J}^{\mathrm{mol}^{-1}}$

Rate constant, $\mathrm{L} \mathrm{mol}^{-1} \mathrm{~s}^{-1}$

Equilibrium constant

Dissociation constant

Thermodynamic constant

Mass, kg

Rotating speed, rps

Volumetric flow rate, $\mathrm{L} \mathrm{s}^{-1}$

Accumulated heat-flow rate, $\mathrm{J} \mathrm{s}^{-1}$

Heat-flow rate due to dosing, $\mathrm{J} \mathrm{s}^{-1}$

Heat-flow rate exchange with heat carrier, $\mathrm{J} \mathrm{s}^{-1}$

Heat-flow rate lossed, $\mathrm{J} \mathrm{s}^{-1}$ 
$q_{\text {reaction }}$

$q_{\text {solvation }}$

$R_{\mathrm{i}}$

$\mathrm{t}$

$\mathrm{T}$

UA

V

$\Delta \mathrm{H}$

$1 / h$

Greek letters

$\mu$

$\lambda$

$\omega$

$\rho$
Heat-flow rate due to chemical reaction, $\mathrm{J} \mathrm{s}^{-1}$

Heat-flow rate of solvation, $\mathrm{J} \mathrm{s}^{-1}$

Reaction rate, $\mathrm{mol} \mathrm{L}^{-1} \mathrm{~s}^{-1}$

Time, s

Temperature, $\mathrm{K}$

Overall heat-transfer coefficient, $\mathrm{W} \mathrm{K}^{-1}$

Volume, L

Enthalpy, $\mathrm{J} \mathrm{mol}^{-1}$

Convective resistance, $\mathrm{K} \mathrm{m}^{-2} \mathrm{~W}^{-1}$

Dynamic viscosity, $\mathrm{kg} \mathrm{m}^{-1} \mathrm{~s}^{-1}$

Thermal conductivity, $\mathrm{W} \mathrm{m}^{-1} \mathrm{~K}^{-1}$

Mass fraction

Density, $\mathrm{kg} \mathrm{m}^{-3}$ 
Subscripts

0

ambient

Cat.

feed

Hydrolysis-cat.

Hydrolysis-non.cat

$i$

ins

$j$

$\mathrm{R}$

S

W

Ref.
Time zero

Ambient

catalyzed reaction

Feed

catalyzed hydrolysis reaction

non-catalyzed hydrolysis reaction

Component $i$

inserts

Jacket

Reaction system

Stirrer

Wall

Reference 
419 This study has been done in the framework of Task 2: "Green process: $2^{\text {nd }}$ generation of 420 biomass" of AMED project. The authors thank AMED project. The AMED project has been 421 funded with the support from the European Union with the European Regional Development 422 Fund (ERDF) and from the Regional Council of Normandie. The authors express their 423 gratitude to Prof. Johan Wärnå for his help in the modeling stage. The authors thank the 424 Ministry of High Education, Science and Technology of Dominican Republic. The authors 425 thank the "Programme Excellence Eiffel". 
427 [1] X. Cai, K. Ait Aissa, L. Estel, S. Leveneur, Investigation of the Physicochemical 428 Properties for Vegetable Oils and Their Epoxidized and Carbonated Derivatives, J. Chem. Eng. 429 Data. 63 (2018) 1524-1533. doi:10.1021/acs.jced.7b01075.

430 [2] Q. Xu, J. Ding, S. Yang, S. Ye, Measurement and calculation method of changing heat 431 capacities during the reaction, Thermochim. Acta. 675 (2019) 55-62. 432 doi:10.1016/j.tca.2019.03.004.

[3] E. Hanitzsch, Messung der spezifischen wärmekapazität - vergleich zwischen DSC434 und pulsmethode, Thermochim. Acta. 151 (1989) 289-293. doi:10.1016/0040-6031(89)853574352.

436 [4] S.Q. Miao, H.P. Li, G. Chen, Temperature dependence of thermal diffusivity, specific 437 heat capacity, and thermal conductivity for several types of rocks, J. Therm. Anal. Calorim. 438115 (2014) 1057-1063. doi:10.1007/s10973-013-3427-2.

439 [5] W.Y. Pérez-Sena, X. Cai, N. Kebir, L. Vernières-Hassimi, C. Serra, T. Salmi, S. 440 Leveneur, Aminolysis of cyclic-carbonate vegetable oils as a non-isocyanate route for the 441 synthesis of polyurethane: A kinetic and thermal study, Chem. Eng. J. 346 (2018) 271-280. 442 doi:10.1016/j.cej.2018.04.028.

443 [6] I. Bylina, L. Trevani, S.C. Mojumdar, P. Tremaine, V.G. Papangelakis, Measurement of 444 reaction enthalpy during pressure oxidation of sulphide minerals, J. Therm. Anal. Calorim. 96 445 (2009) 117-124. doi:10.1007/s10973-008-9883-4. 
[7] R. André, M. Giordano, C. Mathonat, R. Naumann, A new reaction calorimeter and

447 calorimetric tools for safety testing at laboratory scale, Thermochim. Acta. 405 (2003) 43-50. doi:10.1016/S0040-6031(03)00129-1.

[8] S. Leveneur, M. Pinchard, A. Rimbault, M. Safdari Shadloo, T. Meyer, Parameters 450 affecting thermal risk through a kinetic model under adiabatic condition: Application to liquid451 liquid reaction system, Thermochim. Acta. 666 (2018) 10-17. doi:10.1016/j.tca.2018.05.024. hazards simulation of cumene hydroperoxide by DSC, J. Loss Prev. Process Ind. 21 (2008) 454 101-109. doi:10.1016/j.jlp.2007.09.002.

[10] A. Keller, D. Stark, H. Fierz, E. Heinzle, K. Hungerbühler, Estimation of the time to 456 maximum rate using dynamic DSC experiments, J. Loss Prev. Process Ind. 10 (1997) 31-41. doi:10.1016/S0950-4230(96)00037-X.

[11] O.R. Valdes, V.C. Moreno, S. Waldram, L. Véchot, M.S. Mannan, Runaway 459 decomposition of dicumyl peroxide by open cell adiabatic testing at different initial conditions, 460 Process Saf. Environ. Prot. 102 (2016) 251-262. doi:10.1016/j.psep.2016.03.021.

461 [12] Y. Wang, L. Vernières-Hassimi, V. Casson-Moreno, J.-P. Hébert, S. Leveneur, Thermal 462 Risk Assessment of Levulinic Acid Hydrogenation to $\gamma$-Valerolactone, Org. Process Res. Dev. 46322 (2018) 1092-1100. doi:10.1021/acs.oprd.8b00122.

464 [13] A. Zogg, F. Stoessel, U. Fischer, K. Hungerbühler, Isothermal reaction calorimetry as a 465 tool for kinetic analysis, Thermochim. Acta. 419 (2004) 1-17. doi:10.1016/j.tca.2004.01.015. 
[14] L. Vernières-Hassimi, A. Dakkoune, L. Abdelouahed, L. Estel, S. Leveneur, Zero-

Order Versus Intrinsic Kinetics for the Determination of the Time to Maximum Rate under Adiabatic Conditions (TMRad): Application to the Decomposition of Hydrogen Peroxide, Ind. Eng. Chem. Res. 56 (2017) 13040-13049. doi:10.1021/acs.iecr.7b01291.

[15] E. Marco, S. Cuartielles, J.A. Peña, J. Santamaria, Simulation of the decomposition of di-cumyl peroxide in an ARSST unit, Thermochim. Acta. 362 (2000) 49-58. doi:10.1016/S0040-6031(00)00587-6.

[16] I. Dobrosavljevic, E. Schaer, J.M. Commenge, L. Falk, Intensification of a highly exothermic chlorination reaction using a combined experimental and simulation approach for fast operating conditions prediction, Chem. Eng. Process. Process Intensif. 105 (2016) 46-63. doi:10.1016/j.cep.2016.04.007.

[17] M.J. Todd, J. Gomez, Enzyme kinetics determined using calorimetry: a general assay for enzyme activity?, Anal. Biochem. 296 (2001) 179-187. doi:10.1006/abio.2001.5218.

[18] W. Hoffmann, Y. Kang, J.C. Mitchell, M.J. Snowden, Kinetic Data by Nonisothermal Reaction Calorimetry: A Model-Assisted Calorimetric Evaluation, Org. Process Res. Dev. 11 (2007) 25-29. doi:10.1021/op060144j.

[19] T.J. Snee, C. Bassani, J.A.M. Ligthart, Determination of the thermokinetic parameters of an exothermic reaction using isothermal, adiabatic and temperature-programmed calorimetry in conjunction with spectrophotometry, J. Loss Prev. Process Ind. 6 (1993) 87-94. doi:10.1016/0950-4230(93)90005-I. 
[20] S.P. Asprey, B.W. Wojciechowski, N.M. Rice, A. Dorcas, Applications of temperature scanning in kinetic investigations: The hydrolysis of acetic anhydride, Chem. Eng. Sci. 51 (1996) 4681-4692. doi:10.1016/0009-2509(96)00306-5.

[21] F.L. Wiseman, New insight on an old reaction - the aqueous hydrolysis of acetic anhydride, J. Phys. Org. Chem. 25 (2012) 1105-1111. doi:10.1002/poc.2945.

[22] F. Susanne, D.S. Smith, A. Codina, Kinetic Understanding Using NMR Reaction Profiling, Org. Process Res. Dev. 16 (2012) 61-64. doi:10.1021/op200202k.

[23] W.H. Hirota, R.B. Rodrigues, C. Sayer, R. Giudici, Hydrolysis of acetic anhydride: Non-adiabatic calorimetric determination of kinetics and heat exchange, Chem. Eng. Sci. 65 (2010) 3849-3858. doi:10.1016/j.ces.2010.03.028.

[24] A. Zogg, U. Fischer, K. Hungerbühler, A New Small-Scale Reaction Calorimeter That Combines the Principles of Power Compensation and Heat Balance, Ind. Eng. Chem. Res. 42 (2003) 767-776. doi:10.1021/ie0201258.

[25] A. Zogg, U. Fischer, K. Hungerbühler, A new approach for a combined evaluation of calorimetric and online infrared data to identify kinetic and thermodynamic parameters of a chemical reaction, Chemom. Intell. Lab. Syst. 71 (2004) 165-176. doi:10.1016/j.chemolab.2004.01.025.

[26] M.Á. Gómez García, I. Dobrosz-Gómez, J.C. Ojeda Toro, Thermal stability and dynamic analysis of the acetic anhydride hydrolysis reaction, Chem. Eng. Sci. 142 (2016) 269276. doi:10.1016/j.ces.2015.12.003. 

Anhydride at Higher Temperatures using Adiabatic Batch Reactor (Thermos-Flask), in: 2013. doi:10.4172/2157-7048.1000176.

[28] J.L. Zheng, J. Wärnå, T. Salmi, F. Burel, B. Taouk, S. Leveneur, Kinetic modeling strategy for an exothermic multiphase reactor system: Application to vegetable oils epoxidation using Prileschajew method, AIChE J. 62 (2016) 726-741. doi:10.1002/aic.15037. Thermal Safety Assessment: Application to Peroxyformic Acid Synthesis, Ind. Eng. Chem. Res. 51 (2012) 13999-14007. doi:10.1021/ie3017847. exothermic chlorination reaction using a combined experimental and simulation approach for 517 fast operating conditions prediction, Chem. Eng. Process. Process Intensif. 105 (2016) 46-63. 518 doi:10.1016/j.cep.2016.04.007.

519 [31] K. Sue, F. Ouchi, K. Minami, K. Arai, Determination of Carboxylic Acid Dissociation 520 Constants to $350{ }^{\circ} \mathrm{C}$ at $23 \mathrm{MPa}$ by Potentiometric pH Measurements, J. Chem. Eng. Data. 49 521 (2004) 1359-1363. doi:10.1021/je049923q.

522 [32] S. Leveneur, L. Vernieres-Hassimi, T. Salmi, Mass \& energy balances coupling in 523 chemical reactors for a better understanding of thermal safety, Educ. Chem. Eng. 16 (2016) 524 17-28. doi:10.1016/j.ece.2016.06.002. 
[33] http://www.stenutz.eu/chem/solv6.php?name=acetic\%20anhydride, acetic anhydride,

526 (n.d.). http://www.stenutz.eu/chem/solv6.php?name=acetic\%20anhydride (accessed June 29, 527 2019).

528 [34] F. Lavanchy, Development of reaction calorimetry applied to supercritical CO2 and 529 methanol- $\mathrm{CO}_{2}$ critical mixture, Infoscience. (2005). doi:10.5075/epfl-thesis-3228.

530 [35] H. Rakotondramaro, J. Wärnå, L. Estel, T. Salmi, S. Leveneur, Cooling and stirring 531 failure for semi-batch reactor: Application to exothermic reactions in multiphase reactor, J. 532 Loss Prev. Process Ind. 43 (2016) 147-157. doi:10.1016/j.jlp.2016.05.011.

533 [36] H. Haario, MODEST-User's Guide, (2001).

534 [37] H.-Y. Wei, Z.-C. Guo, L. Hao, W.-S. Bai, R. Wang, S. Li, identification of the kinetic 535 parameters and autocatalytic behavior in esterification via isoperibolic reaction calorimetry, 536 Org. Process Res. Dev. 20 (2016) 1416-1423. doi: 10.1021/acs.oprd.5b00395 